\title{
Legal Consequences on PPAT Deed Not Made in Accordance with the Provisions Case Study of Court Decision No.137 / PID.B / 2016 / PN.PBR
}

\author{
Mhd. Mora Kamis Nst; Elwi Danil; Beatrix Benni \\ Faculty of Law, Andalas University, Padang, Indonesia \\ http://dx.doi.org/10.18415/ijmmu.v6i5.1100
}

\begin{abstract}
The notary profession that can concurrently serve as a PPAT is one of the professions that has taken part in the process of law enforcement in Indonesia by providing certainty, order and legal protection in the community, especially in terms of the need for a binding evidence in addition to witness evidence, which is in the form of making authentic evidence. The notary profession is also required to be able to provide legal certainty to the parties, which means that anyone who holds the position of a notary must comply with statutory provisions, as well as PPAT in carrying out his position. But in reality what happens is that there is still a lot of work done by notaries or PPAT which ultimately has legal implications for the authority carried out by notaries or PPAT, so that the public, especially the parties involved in the deed, become confused in seeking legal certainty and in a manner indirectly can cause huge material losses to people who need justice. Research data were collected through field studies through interviews with resource persons to obtain primary data and literature studies to obtain primary data. The focus of this research is to find out and analyze how the legal consequences of the deed made not in accordance with the provisions of the case study court decision no.137 / pid.b / 2016 / pn.pbr. The results of the study showed that 1) PPAT which was proven to have committed a crime of counterfeiting was responsible for his sentence with a prison sentence of 1 (one) Year 8 (eight) Months. 2) The legal consequences of the deed made are not in accordance with the provisions of the legislation because it contains elements of forgery, the deed is null and void by law and for the certificate of transfer of land rights issued with the deed as the basis, then with the court's decision the judge has stated that the certificate the legal defect and cancellation can be requested to the local Office of the Land Agency.
\end{abstract}

Keywords: Legal Consequences; PPAT; Deed

\section{Background of Research}

Notary as Public official is authorized to make an authentic deed and other authorities as referred to in the Law of Notary Position. Notary is a profession that plays an active role in supporting the process of law enforcement in the Unitary State of the Republic of Indonesia. Regarding the existence of a notary in Indonesia, it is illustrated in article 1868 of the Civil Code that states: 
"An authentic deed is a deed which in its form is determined by a law made by or in front of public officials in power to the place where the deed was made".

Related to that in 2004 issued Law Number 30 of 2004 concerning Notary Position (as a substitute for Staatblad 1860 Number 30) hereinafter referred to as UUJN which was later amended by Law of the Republic of Indonesia Number 2 of 2014 concerning Amendments to Law Number 30 of 2004 concerning Notary, hereinafter in this article called UUJN. Notary as public officials are obliged to obey and obey all laws and regulations relating to notaries and the conditions that must be fulfilled so that a deed is perfect and can guarantee the authenticity of a deed made by the notary.

There are 3 (three) authentic deed functions for the parties who promised or made them, namely:

1. As evidence the parties concerned have entered into an agreement.

2. As evidence for the parties that what has been written in the agreement is the aim and desire of the parties.

3. As evidence to the third party that on a certain date unless otherwise specified the parties have entered into an agreement and that the contents of the agreement are in accordance with the wishes of the parties. ${ }^{1}$

Notary as a public official to him is demanded responsibility for the deed he made. If the deed made behind the day contains a dispute then this needs to be questioned, whether the deed was a notary error or the fault of the parties who did not provide data and documents properly and the parties gave incorrect information outside the notary's knowledge or an agreement which is made between a notary and one of the parties facing. If the notary deed contains legal defects due to notary errors either due to negligence or intentional notary itself, then the notary must provide accountability both morally and legally. ${ }^{2}$

To avoid or formally appear flawed from a deed made before or by a notary public, a notary must be guided in making a deed whose form has been determined in Article 38 of the UUJN, and most importantly the Notary in carrying out his position must act honestly, thoroughly, independently, impartiality and safeguard the interests of those involved in the legal action as mentioned in Article 16 UUJN.

The notary profession that can concurrently serve as a PPAT is one of the professions that has taken part in the process of law enforcement in Indonesia by providing certainty, order and legal protection in the community, especially in terms of the need for a binding evidence in addition to witness evidence, which is in the form of making authentic evidence. Notary profession are required also to be able to provide legal certainty to the parties, which means that anyone who runs a notary office must be in accordance with the provisions of the laws, as well as in the running position as Notary PPAT, which forms his deed has been determined.

According to Article 2 number 1 Government Regulation Number 37 of 1998 the main task of the PPAT is to carry out part of the land registration activities by making a deed as proof of certain legal actions regarding land rights or ownership rights for a Flats, which will be the basis for registering changes in data land registration caused by the legal acts. Where legal actions are intended namely:

\footnotetext{
${ }^{1}$ Salim, HS, Contract Law, Theory and Technique of Drafting Contracts, Sinar Grafika, Jakarta, 2006, p. 43.

${ }^{2}$ Putri AR, Legal Protection of a Notary (Duties of Notary Offices with Implications for Criminal Acts), Sofmedia, Jakarta, 2011, p. 8.
} 
1. Buying and selling

2. Exchange

3. Grants

4. Inbreng

5. Sharing of common rights

6. Granting of building use rights / use rights on Freehold Land

7. Granting mortgage rights

8. SKMHT

The interesting thing here is the fact that there is still a lot of work done by a notary or PPAT which in turn has legal implications for the authority received by the notary public, so that the public, especially the parties involved in the deed, are confused in seeking certainty law. Can indirectly cause huge material losses to people who need justice. If the PPAT in exercising its authority in making an authentic deed does not meet the applicable provisions, the PPAT can be deliberately suspected together with the parties or one of the parties to make the deed with the aim of benefiting the parties or one of the parties, this of course must be proven through a court.

One of them such as the Notary PPAT reporting cases by one of the parties was never signed AJB has been made by Notary PPAT as such, resulting in the complainant suffering losses due to the transfer of ownership of the land certificate ownership to another person. The problem began with accounts payable between the parties, where the loan agreement amounted to Rp 600,000,000 six hundred million rupiah) between Nurbaini as the certificate holder and Mardiana as the borrower of money with guarantees of land certificates made with a notarial deed, with an agreement in which one of the parties will pay off within two months, but before two months the party who holds the land certificate will sell the land as debt service and consider the previous debt as a down payment.

Along the way, suddenly appeared Deed of Sale and purchase of land as collateral, while Nurbaini feel has never been sold through a deed made by the notary, with the suspicion has been buying and selling by the deed of AJB that unbeknownst to her, then Nurbaini reporting to the Directorate Riau Police General Criminal Investigation.In a court ruling in the first instance, the judge stated that the Notary and Mardiana were legally declared to have committed a criminal offense that harmed Nurbaini by falsifying signatures as evidenced by the results of the Medan Forensic Laboratory (LabFor) test.

Based on the description above, the author aims to analyze the case of the Notary as PPAT Puji Sunanto based on the Court decision number 137 / PID.B / 2016 / PN.BR which is proven to falsify the deed he made especially concerning the signing of the deed which is an important requirement in making a deed, and to accommodate the interests of the discussion of the above problems, the authors are interested in conducting research in a scientific work in the form of a thesis with the title Legal Consequences On Deed of Act That Is Made Not In Accordance with the Provisions Laws Case Study of Court Decision No.137 / Pid.B / 2016 / Pn.Pbr)

\section{Research Methods}

The method used in this thesis research is empirical juridical research, which is research based on field research to get primary data in the field of law. The specifications of this study are descriptive analysts, because this study is expected to obtain data that clearly illustrate what is discussed in this study. The type of data used in this study are primary and secondary data, where secondary data consists of 
Primary, Secondary and Tertiary Legal Materials. The data collection techniques used for research in the field are interviews and study of documentation documents. While the data obtained from this research will be analyzed using qualitative methods, namely analysis of data without using statistical formulas because the data used are not in the form of numbers. Thus what is used is only by logical explanation of the sentence based on the rules and opinions of experts.

\section{Result of Reasearch and Discussion}

Responsibility of Notary Public as PPAT Against Cancellation of Deed Based on Court Decision No.137 / Pid.B / 2016 / PN.PBR

In this case study shows the presence of the judge's decision in the imprisonment against the case being researched for 1 (one) years and 8 (eight) months is appropriate. In this case the judge did not in terms of being hesitant in taking decisions, because the judges viewed from the evidence and the facts found in the trial and the judge referred to Article 264 of the Criminal Code. The research also shows that the overall actions or efforts carried out by Pekanbaru Police investigators in improving the status of cases from investigation to the investigation stage are in accordance with established mechanisms and procedures. All actions or legal remedies carried out by the investigator when receiving reports from sister reporter Nurbaini to the determination of the status of the suspect in the PPAT all have clear legal reasons that have been regulated in the Criminal Code and the Criminal Procedure Code.

The judge's statement stated that it had been proven as facts in the trial which were clearly Labfor results which stated that the signature was non identical or fake and was very relevant to PPAT in the case of the author who adopted the PPAT together with reported Mardiana without as informed by the reporter Nurbaini.

Making a fake letter is making a letter that is wholly or part of its contents fake. False means that it is not true or contrary to the real situation. In addition to the contents and origin of an incorrect letter from making a false statement, there is also an incorrect signature. In fact, almost all of these deeds contain false information. Starting from the beginning of the deed which states the parties are present but in reality the parties have never met with the Notary / PPAT, then on the premise of the contents of the letter stating the sale and purchase agreement was held when in reality there was never a sale and purchase, and also at the end the deed, which is the thumbprint that is listed as the agreement of the parties is also fake. So it is clear that both the contents of the deed and thumbprint of this deed are fake. Then in the next sentence of this element which states that it can give rise to a right, an agreement or a debt relief, or that is intended as evidence rather than something. This element has also been proven because with the issuance of the sale and purchase certificate, ownership rights were transferred. The element with the intention to use or use or order others to use as if the contents are true and not fake, has also been fulfilled because with the issuance of Deed of Sale and Purchase Number 68/2012, September 27,2012 , it is still used as if it were genuine and not forged by the defendant is reversed from the seller's name to the buyer and then used as collateral at the bank. The element, if the use of the letter brings loss. This element has also been fulfilled and Nurbaini suffered losses due to the sale and purchase deed that was made before the PPAT.

The results of the study showed that the PPAT responsibility in the event of falsification of letters by the parties in making the PPAT deed was when PPAT in carrying out their position was proven to have violated, the PPAT was responsible in accordance with the actions carried out both in terms of administrative and civil law as stated in Article 3 letter (e) of the Code of Ethics of the Official for 
Making Land Deeds stating that a PPAT must have a sense of responsibility, be independent, be honest, and be impartial.

If we look at those related to criminal sanctions in the PPAT code of ethics there is no article found that regulates criminal sanctions. In practice it is found that the violation of the sanctions is then qualified as a criminal offense committed by the PPAT. In this case, if the PPAT is not carried out as specified in the PPAT code of ethics, it can lead to falsification of deeds as referred to in Articles 263, 264, and 266 of the Criminal Code. So PPAT in this case can be held accountable for their criminal damages arising out against one of the parties as their fake signature in a document created by the PPAT. All the false deeds committed by one of the parties is the responsibility of the parties themselves, but in this case the PPAT participate participate, then melekatlah criminal liability in the PPAT.

\section{Legal Consequences On Ppat Deed Not Made In Accordance With The Provisions (Case Study Of Court Decision No.137 / Pid.B / 2016 / Pn.Pbr)}

In this case, as has been proven and has been decided by the judge that the PPAT official has committed a criminal act of forgery in making his deed and this is certainly not in accordance with the provisions of the legislation related to the PPAT code of ethics itself, thus the deed was canceled law. The fake deed is then used to register the transfer of rights, and the certificate is issued by the BPN. The issuance of a certificate with a fake deed as a basis and results in a legal defect certificate and cancellation can be requested and no longer valid and withdrawn from circulation. Reporting parties in the case of certificate revocation can make a court determination request for the certificate revocation because the PPAT deed which is the document that underlies the certificate issuance is fake.

Specifically the issue of falsification of signatures on the PPAT deed so that a certificate arises for someone who is not entitled to it, and causes loss of sense of justice to the injured party. and result in the arising of uncertainty of what is due. For this reason, PPAT certainly has to bear the legal consequences of such matter as referred to in Article 55 Law No. 1 In 2006, PPAT to take personal responsibility for the implementation of tasks and positions in every deed deed whereby each giving incorrect information in the certificate is included breach by PPAT can be penalized dishonorable discharge from office by the National Land Agency of Indonesia.

After the court's verdict in this case it was clearly seen that the legal consequences of the forgery carried out by the defendant resulted in the certificate being transferred on behalf of Mardiana to be legally flawed. So the reporting party has the right to return the certificate in its own name. Because of a court ruling stating that the defendant was legally proven to have committed a criminal offense.

If there is a legal defect in the certificate the first step that must be taken is to file a complaint or submit a certificate cancellation. Cancellation can be made by making the complaint to the office of the National Land Agency based on the lawsuit to the District Court. The lawsuit is related to KUHP Article 264 or in the case of authentic deed falsification. Because the BPN Office does not have authority in the matter of certificate cancellation, the injured party submits a civil suit to demand the cancellation so that the judge decides and grants the certificate revocation. With the judge's decision is legally binding in the case of a judge ordered the head of BPN (National Land Agency) to revoke the certificate and restore land rights to those entitled.

With the establishment of the court, the reporting party can request to the National Land Agency through the Head of the local Land Agency Office to issue a new certificate, based on the court's decision. So that the reporter gets legal certainty from problems that harm the reporter. The regulation on the mechanism for revoking land ownership certificates is regulated in National Land Agency Decree No. 3 
of 2011 concerning Management, Study and Handling of Land Cases. More detailed rules are contained in paragraph 3 of Article 1, namely:

(1) In the case of above one plot of land there are several certificates of overlapping land rights, the Indonesian National Land Agency conducts a legal action on land in the form of cancellation and / or issuance of certificates of land rights, so that above the land parcel there is only one certificate of land rights legitimate.

(2) Administrative law defects that may result in invalidation of a certificate of land rights must be strengthened with evidence in the form of:

a. court decisions that have permanent legal force; and / or

b. research results that prove the existence of administrative law defects; and / or

c. statement from the investigator regarding the criminal act of falsification of letters or information used in the process of issuing, transferring or canceling certificates of land rights; and / or

d. other letters indicating administrative defects

\section{Conclussion}

With the decision of the judge who has been fixed on this case, the PPAT which is proven to have committed a criminal offense is responsible for his actions with a prison sentence of 1 (one) Year 8 (eight) Months. The legal consequences of the deed made are not in accordance with the provisions of the legislation because it contains elements of forgery, the deed is null and void by law and for the certificate of transfer of land rights issued with the deed as a basis, then with the court's decision the judge has stated that the certificate is flawed legal and cancellation can be requested to the local Office of the Land Agency.

\section{Reference}

\section{Books}

Salim, HS, Contract Law, Theory and Technique of Drafting Contracts, Sinar Grafika, Jakarta, 2006, p. 43.

Putri AR, Legal Protection of a Notary (Duties of Notary Offices with Implications for Criminal Acts), Sofmedia, Jakarta, 2011, p. 8.

\section{Copyrights}

Copyright for this article is retained by the author(s), with first publication rights granted to the journal.

This is an open-access article distributed under the terms and conditions of the Creative Commons Attribution license (http://creativecommons.org/licenses/by/4.0/). 